\title{
Isumaqatigingniq: Building a Transformational Science Education Model to Engage the Next Generation of Inuit and Western Scientific Investigators
}

\author{
Martin T. Nweeia ${ }^{1}$ and Pamela Peeters ${ }^{2}$
}

(Received 2 October 2020; accepted in revised form 3 May 2021)

\begin{abstract}
Inuit Qaujimajatuqangit (IQ), "the Inuit way of knowing," and science each approach observation of the natural and physical world from shared yet different epistemologies. Studies that integrate IQ and science demonstrate the inherent value of using observations and findings from both to understand Arctic systems. Yet holders of IQ and scientists often do not fully comprehend the practice of the other because they think and approach observation and knowledge differently. Using the concept of Isumaqatigingniq, or "thinking together," we will form an educational program, Isumaqatigingniq-Science, Technology, Engineering and Mathematics, (I-STEM), that will highlight and integrate studies of the narwhal and the Arctic environment undertaken with contributions from IQ and science. Program outreach will target high school students from both Inuit and non-Inuit backgrounds. Understanding existing efforts that combine these knowledge frames will hopefully inspire future collaborations by these groups. Learning through I-STEM will better equip students to address scientific themes that design, optimize, and implement collaborative observation systems. Inuit and scientific research efforts are essential for a deeper understanding of the Arctic environment. Implementing an active educational program that engages high school youth to understand the value of incorporating these two ways of knowing will help foster a future educational environment of collaboration. The educational I-STEM model will bring a new Inuit perspective to formal scientific education programs and share perspectives of science and Inuit knowledge within Inuit educational programs. Isumaqatigingniq can continue growing, incorporating new perspectives on Arctic observations and knowledge.
\end{abstract}

Key words: Arctic; Inuit; Isuma; Isumaqatigingniq; STEM; United Nations; sustainable goals; environment; Qaujimajatuqangit; education; narwhal

RÉSUMÉ. L'Inuit Qaujimajatuqangit (IQ), soit « la façon de savoir des Inuits », et la science abordent toutes deux le monde physique et le monde naturel à partir d'épistémologies partagées, quoique différentes. Les études qui font appel à l'IQ et à la science démontrent la valeur inhérente de recourir aux observations et aux constatations de ces deux branches pour comprendre les systèmes arctiques. Pourtant, il arrive souvent que les détenteurs de l'IQ et les scientifiques ne comprennent pas entièrement la pratique de l'autre parce qu'ils considèrent et approchent l'observation et les connaissances différemment. En nous appuyant sur le concept de l'Isumaqatigingniq, ou de la « réflexion collective », nous formerons un programme éducatif appelé Isumaqatigingniq-science, technologie, ingénierie et mathématiques (I-STEM), qui mettra en évidence et intégrera les études sur le narval et l'environnement arctique réalisées à l'aide de l'IQ et de la science. Ce programme visera les élèves du secondaire deuxième cycle, inuits et non inuits. Le fait de comprendre les efforts actuels faisant appel à ces deux cadres de connaissances inspireront, espérons-le, des collaborations futures de la part de ces groupes. Grâce aux apprentissages faits par le biais du programme I-STEM, les élèves seront mieux outillés pour aborder les thèmes scientifiques donnant lieu à la conception, à l'optimisation et à la mise en œuvre des systèmes d'observation collaboratifs. Les efforts de recherche menés à bien par les Inuits et les scientifiques sont essentiels à une compréhension approfondie de l'environnement arctique. La mise en œuvre d'un programme éducatif actif incitant les jeunes de l'école secondaire deuxième cycle à comprendre la valeur de l'incorporation de ces deux méthodes de connaissances aidera à favoriser un milieu éducatif axé sur la collaboration. Le modèle éducatif I-STEM permettra d'intégrer une nouvelle perspective inuite aux programmes d'éducation scientifique officiels et de partager les perspectives des connaissances de la science et des Inuits à l'échelle des programmes éducatifs inuits. L'Isumaqatigingniq peut permettre de continuer à cultiver et à incorporer de nouvelles perspectives sur les observations et les connaissances propres à l'Arctique.

Mots clés : Arctique; Inuit; Isuma; Isumaqatigingniq; STEM; Nations Unies; objectifs durables; environnement; Qaujimajatuqangit; éducation; narval

Traduit pour la revue Arctic par Nicole Giguère.

\footnotetext{
${ }^{1}$ Harvard University, School of Dental Medicine, Department of Restorative Dentistry and Biomaterials Sciences, 188 Longwood Ave., Boston, Massachusetts 02115, USA; Case Western Reserve University School of Dental Medicine, 10900 Euclid Ave., Cleveland, Ohio 44106-7401, USA; Smithsonian Institution, Department of Vertebrate Zoology, 1000 Jefferson Drive SW, Washington, D.C. 20004, USA; Canadian Museum of Nature, 240 McLeod St, Ottawa, Ontario K2P 2R1, Canada; martin_nweeia@hsdm.harvard.edu

${ }^{2}$ Vrije Universiteit Brussels, Boulevard de la Plaine 2, 1050 Ixelles, Belgium

(C) The Arctic Institute of North America
} 


\section{INTRODUCTION}

The formation of an educational program through the Inuit process of Isumaqatigingniq, or "thinking together," is in the final stages of development. Isumaqatigingniq-Science, Technology, Engineering and Mathematics (I-STEM) has brought Inuit leaders in the eastern Canadian Arctic together with recognized scientists from the United States and Canada to highlight and integrate studies of the narwhal and Arctic environment completed by the author and collaborating teams over the past 20 years. The new I-STEM educational platform will be directed at high school students and seeks to transform STEM education to include Inuit Qaujimajatuqangit (IQ), the Inuit way of knowing, and scientific results about the narwhal and the Arctic environment.

Useful, complementary, and insightful, IQ has application and purpose in scientific research when explored as a different epistemology (Wenzel, 1991; Krupnik et al., 2005; Gearhead et al., 2006; Krupnik, 2009) and can be utilized to better understand developing changes in the Arctic environment (Moore and Huntington, 2008; Huntington, 2011). Although both terms cover a range of concepts and approaches (Agrawal, 1995), some broad differences between Inuit and Western scientific knowledge approaches are apparent from our prior work (e.g., Nweeia, 2020) and the work of others (Huntington, 2000, 2002; Gearheard et al., 2006; Rapinski et al., 2018). These contrasts include:

1) Isuma, defined as wisdom, to think or thinking, is contextual, with careful consideration of many variables that the observer needs to integrate before passing the results on as oral knowledge or IQ, since it is often linked to survival in the Arctic. This concept contrasts with scientific methodology, which is reductionist, isolating an observation to be examined and repeated for verification (Nweeia, 2020) and, once verified, disseminated through peer-reviewed publications.

2) An Inuk using IQ is inextricably linked to the land and sees him or herself as part of the land when observing their environment. Scientists see themselves as observers of nature, living most of their lives in environments separated from it.

3) Inuit use their knowledge as a time-dependent survival mode of decision making in an often unforgiving environment to reach long-term conclusions, while scientists collect data, often in controlled, segmented time periods that can take years to process and find results.

4) Inuit IQ, a term that literally translates to "that which Inuit have always known to be true" (Moore and Galway, 2018), is an oral tradition that values and passes on for future generations the keen and sometimes privileged observations of respected and perceptive members of the Inuit community. Scientific methodology is formed from a hypothesis and produces written documentation based on empirical or measurable evidence that can be reproduced based on very specific principles of reasoning.

5) Mythology and careful interpretation of dreams are integrated more in the Inuit educational process. The value of such legends and myths will be included as it relates to Inuit epistemology. Some examples of relevant materials are the "Memory and History in Nunavut Series" from the Interuniversity Centre for Aboriginal Studies and Research (e.g., Oosten et al., 2012); "Angakkuiit (Shaman Stories)," a video that features stories of personal connections to shamanism in Inuit culture from Igloolik Isuma Productions (Isuma TV, 2003); and Stories of the Amautalik: Fantastic Beings from Inuit Myths and Legends (Christopher et al., 2009), a book about traditional stories that offer important life lessons to Inuit children which was highly recommended by CM Magazine.

Understanding narwhal ecology is linked to the social, economic, and environmental changes impacting this extraordinary marine mammal in a region that is the focus of world attention for abundant resources, development, and a rapidly changing ecosystem. The United Nations General Assembly's adoption of 17 sustainable development goals in 2015 (United Nations, 2015) marked a world focus on recognizing society's priorities for treating our planet with renewed sensitivity and respect (Costanza et al., 2016). Goals 4, 5, and 8-17, which are integrated within this educational program, include 4) quality education, $5)$ gender equality, 8) decent work and economic growth, 9) industry, innovation, and infrastructure, 10) reduced inequality, 11) sustainable cities and communities, 12) responsible consumption and production, 13) climate action, 14) life below water, 15) life on land, 16) peace, justice, and strong institutions, and 17) partnerships for the goals. Science education goals in America and Canada focus on the value of integrating sustainable goals into all STEM learning and are thus a valued component in developing educational modules with narwhal and the Arctic environment as the central subjects.

Previous efforts to combine the scientific and educational values of IQ and Western science have been initiated and implemented in the eastern Canadian Arctic and their value demonstrated. These include marine resource management programs (Alexander et al., 2019; Kourantidou et al., 2020), cooperative projects of the Canadian High Arctic Research Station in Cambridge Bay (Burke, 2019), inclusion of IQ knowledge about Arctic climate change at the National Snow and Ice Data Center (Weatherhead et al., 2010), and SmartICE, which, in collaboration with the Nunatsiavut government, integrates traditional knowledge about the ice with real-time data gathered from sensors embedded in sea ice (Halliday, 2020).

Education programs around the world have begun the process of Indigenous knowledge inclusion to acknowledge 

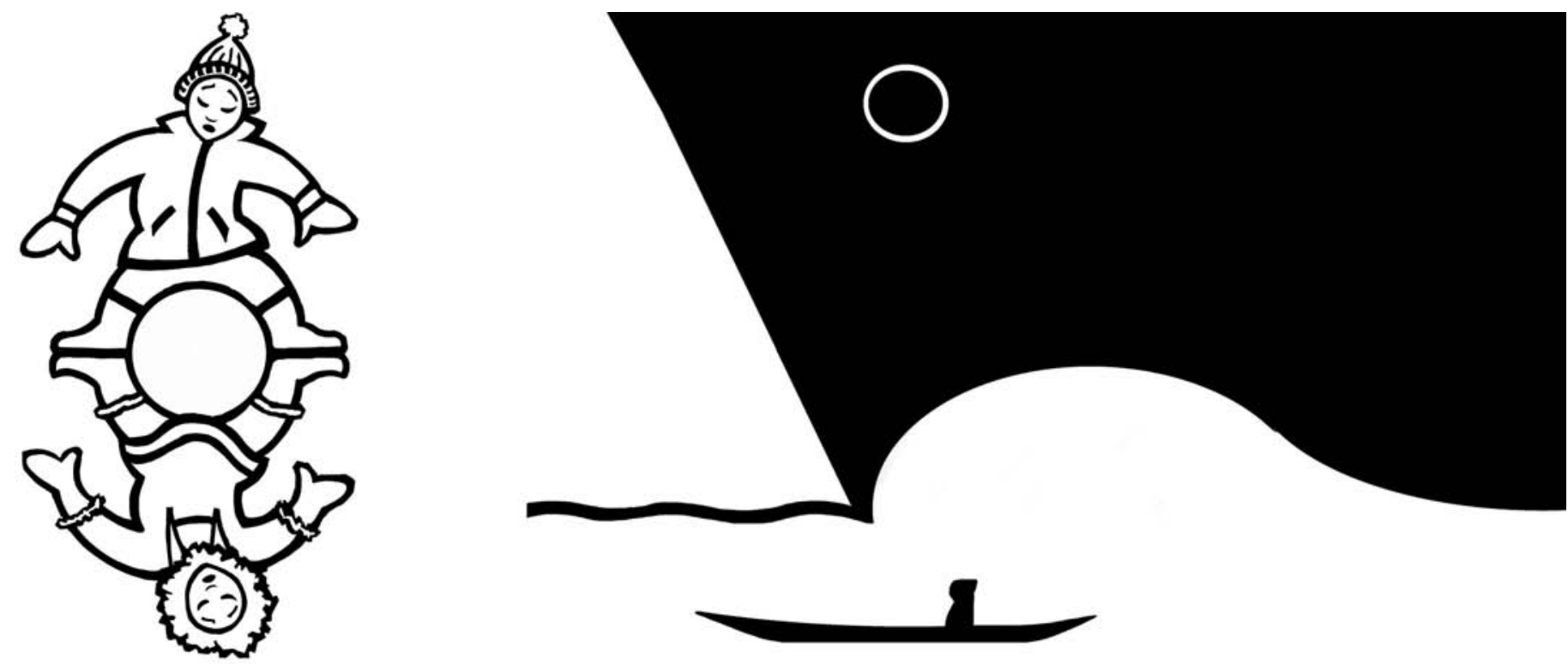

FIG. 1. Sample educational module graphic illustrations depicting (left) Inuit acculturation to Western influence and (right) tourism and development overshadowing Inuit lifestyle. Credit: Joseph Rohde, Creative Director, Walt Disney Imagineering.
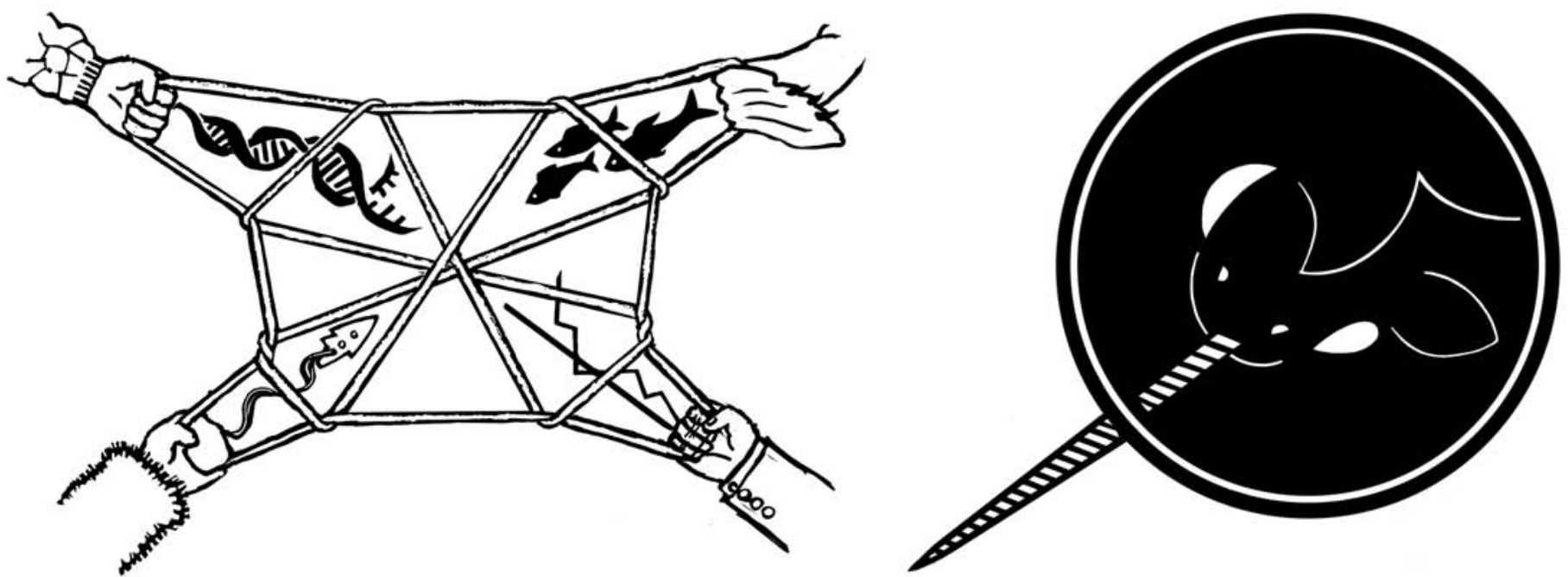

FIG. 2. Module illustrations graphically representing (left) Inuit string games showing the tensions of nature, business, Inuit and science and (right) the narwhal as an Inuit drum. Credit: Joseph Rohde, Creative Director, Walt Disney Imagineering.

its value and motivate students with differing cultural perspectives and values (Swift, 1992; Barnhardt and Kawagley, 2005; Riggs, 2005; Shizha, 2007; Green, 2008; Ng'Asike, 2011). For example, the educational system in Canada has started transforming science education to include IQ (Snively and Corsiglia, 2001; Aikenhead and Elliott, 2010). Modifications in the educational system of Canada and Nunavut have recognized the value of and become more inclusive of IQ and Isuma in their curricula development.

\section{METHODOLOGY}

I-STEM builds on and develops these models with Inuit observations and scientific results of narwhal anatomy, physiology, migration, distribution, and behavior that combine with environmental studies collected over the past 20 years under two Nunavut Research Institute licenses. Content for the program is partially derived from published studies of the Arctic environment and narwhal that combine IQ and science (Krupnik, 2009; Nweeia et al, 2017, Richard, 2019; Nweeia, 2020). Additional content, organization, and input will be made during field research planned for 2021 at designated locations in Ottawa, Iqaluit, and Pond Inlet, and under license approval under the Nunavut Research Institute.

I-STEM is developing six print modules, each 12 to 15 pages with three to four pages of graphics and illustrations (Figs. 1, 2) from both Inuit (Figs. 3, 4) and Western perspectives (Fig. 5) integrated with the content. It is also developing six 12-minute video educational modules that will cover the areas of 1) social impacts to narwhal biology, 2) environmental impacts to narwhal ecology, 3) economic 


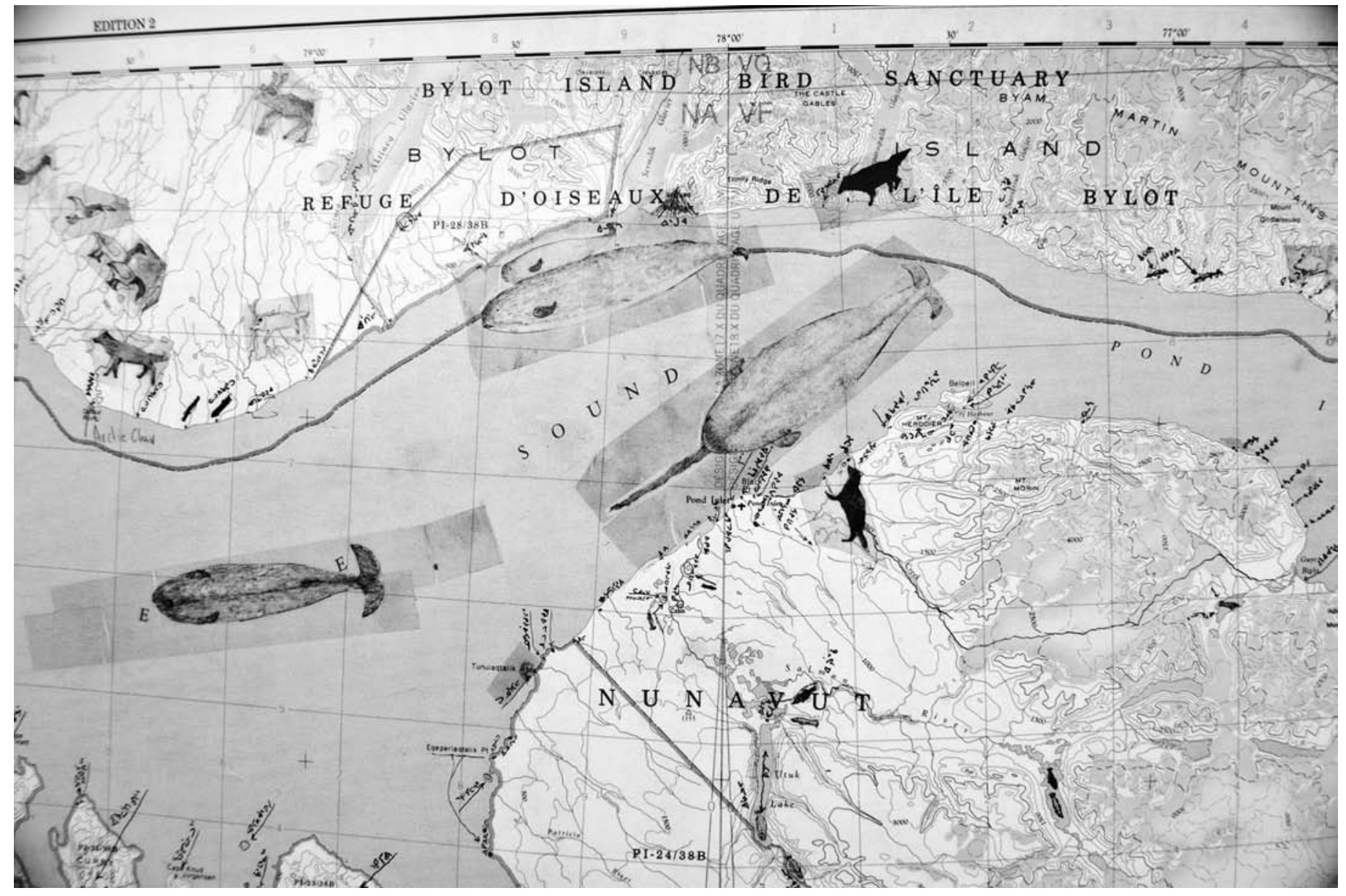

FIG. 3. Map by Inuit elder Cornelius Nutarak showing animal migration patterns and seasonal locations identified with Inuit names.

impacts of a changing Arctic ecosystem, 4) STEM as related to narwhal studies and their relationship to IQ, 5) Inuktitut language, culture, and entrepreneurship issues directly related to the development of job opportunities created by the first four categories, and 6) a case study that includes elements of the first four categories. Written, graphic, and visual content will be balanced amongst Inuit and non-Inuit contributors at all points of development from concept to dissemination.

The first three modules represent sustainable pillars of social, environmental, and economic impact. The effects on narwhal from each of these perspectives will generate discussion from real-time events occurring in the High Arctic. Examples will draw on the effects on narwhal due to natural resource extraction, noise pollution from seismic testing, changing weather and ice patterns affecting hunting, and social impacts to an Inuit subsistence culture. Addressing and solving these problems will be the result of strong partnerships, and empowering minds of all genders with quality education. These modules all relate to STEM education goals, the topic of the fourth module. As an example of knowledge gained through the union of scientific perspective and IQ, when we first examined narwhal tusks and were informed by Inuit hunters that they could bend and flex in all directions, such an observation was difficult to comprehend. Years later, under materials evaluation of strength and flexibility, the narwhal tusk was found to be the most extreme in both values simultaneously. It was determined that a nine-foot tusk could bend and flex $12^{\circ}$ in all directions (Eichmiller, pers. comm., 2013). The fifth module, "Inuktitut, Culture and Entrepreneurship," is usually attached to STEM as ICE-STEM. This module will focus on language and translation as they relate to meaning and interpretation. Cultural aspects including recognition of authorship and contributions to scientific studies, as well as professional science perceptions of IQ, will be discussed. Since all this collected knowledge relates to future jobs and educational pathways, establishing a means to develop job opportunities in different cultural frames will be discussed. Boundary spanners including Narwhal Tusk Research, the Institute for a Sustainable Planet, Nunavut Research Institute, Reach the World, Inuit Tapiriit Kanatami, and the Canadian Museum of Nature have agreed to partner in formulating solutions to knowledge development in this proposed program as it relates to educational development and job opportunities. The sixth module will integrate themes from the first five modules into a case study that offers an open essay or video response.

The modules will be developed in both print and video formats, and both pathways will be encouraged among 


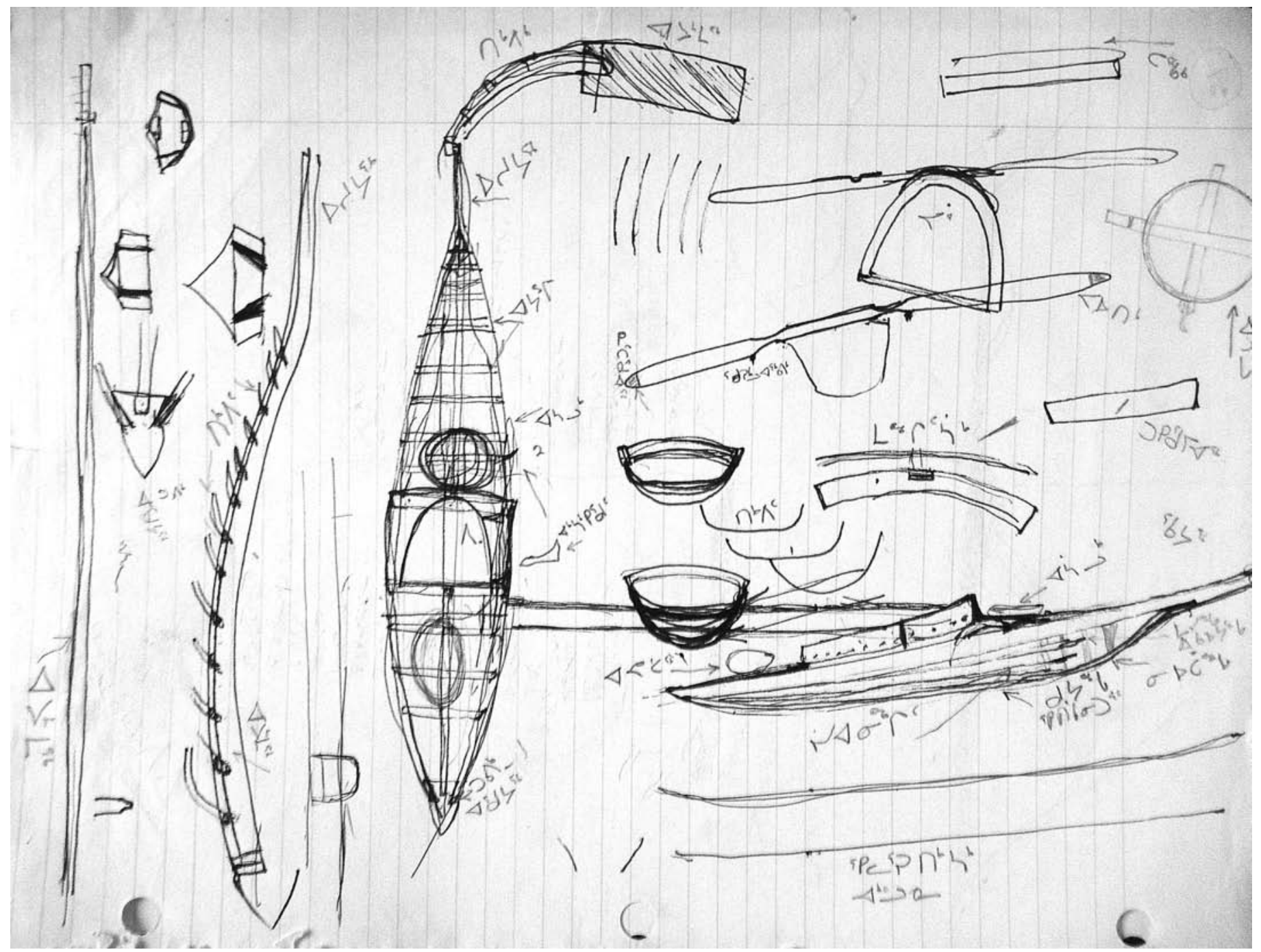

FIG. 4. Illustration by Cornelius Nutarak showing kayak construction and hunting implements.

student groups that experience this educational program. Video format was sought as an alternative pathway since IQ and Isuma are predominantly based in oral tradition; print formats, though useful, may be less effective without including a visual format. Coursework and case studies in environmental science (Peeters, 2013, 2017) and research and IQ on the narwhal (Nweeia et al., 2009, 2012, 2014; Fontanella et al., 2011) will mark the initial content of the course, though other areas of interest will be gathered during the process. Both Isuma and scientific methodology approaches will be taken to engage each student group and integrated into one approach, which will be launched to pilot Inuit school programs in Pond Inlet, Iqaluit, and the Connecticut public school system at Housatonic Valley Regional High School. Preliminary arrangements have already been established in designated schools receptive to including this pilot program as part of their educational electives. Arrangements will be made for a synchronous conferencing session between Inuit and non-Inuit school programs to exchange experiences and foster new relationships for social emotional learning. Asynchronous conferencing will be made available to more remote Inuit youth who may be unable to readily access the program but express interest. Dissemination of print materials and video modules will be made to educational centers through external hard drives to avoid issues of online access.

\section{CONCLUSION}

By integrating Isuma and the scientific methodology, this pilot study will focus on the value of combining IQ and Western science to show the benefits of both worldviews for better understanding Arctic physical and life sciences. Pathways for understanding are mutually beneficial as students in Western science can learn from the original Inuit Arctic sustainable environmentalists, and Inuit can more actively engage and participate with scientific publications that can influence and determine their lifestyle. This program may also serve as an educational reconciliation to recognize and elevate the Qaujimajatuqangit and Isuma of the Inuit and its benefit to a greater understanding of 


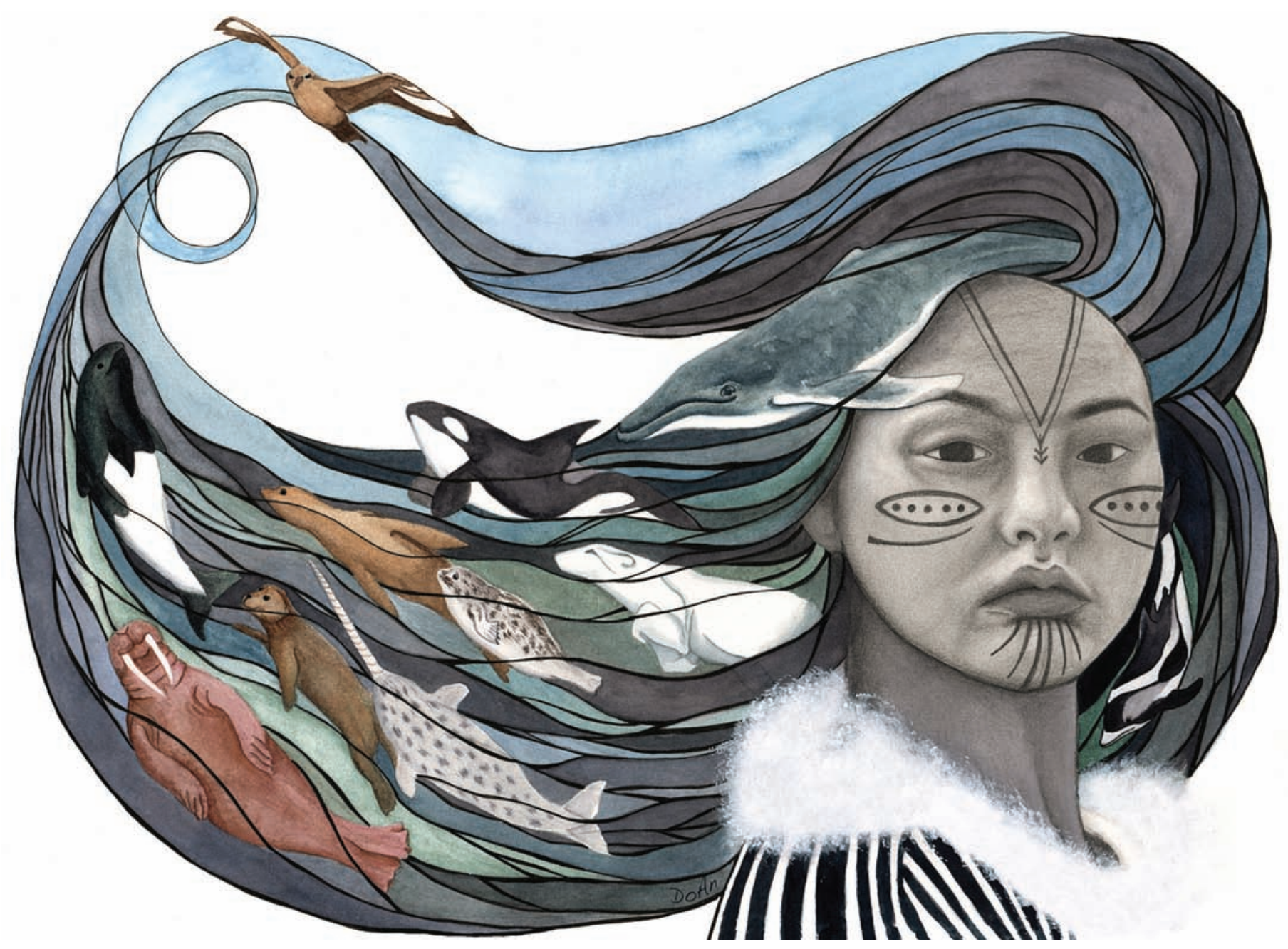

FIG. 5. Sedna painting, Antony Galbraith, 2020 (https://doan-art.pixels.com/).

the Arctic. Western students may become more sensitive to other approaches in science and more motivated to be inclusive of Isuma and Inuit perspective and knowledge. The success of this educational program will be assessed by external, independent evaluators who will conduct formative and summative evaluations. The purpose of the evaluations will be to provide data on the progress the research team is making in reaching its targeted outputs, outcomes, and overall goals.

\section{ACKNOWLEDGEMENTS}

The authors would like to gratefully acknowledge over 65 Inuit hunters from the eastern Canadian High Arctic communities of Mittimatalik (Pond Inlet), Ikpiarjuk (Arctic Bay), Naujaat (Repulse Bay), Iqaluit, Qikiqtarjuak (Broughton Island), and Kangiqtugaapik (Clyde River) as well as the western Greenland High Arctic communities of Hundje Ijland, Disko Island, Illusiat, Uummannaq, and Qaanaaq. Hunters from these communities have actively participated in four published peer-reviewed articles, five museum exhibits (two in the United States, two in Canada, and one in Greenland), and eight educational videos including documentaries. Thank you to the National Science Foundation, Arctic Studies Center, Smithsonian Institution, Inuit Tapiriit Kanatami, the Explorers Club, the Nunavut Research Institute, the United States Embassy in Canada, and the Prince Albert II Foundation of Monaco and Canada.

\section{REFERENCES}

Agrawal, A. 1995. Dismantling the divide between Indigenous and scientific knowledge. Development and Change 26(3):413-439. https://doi.org/10.1111/j.1467-7660.1995.tb00560.x

Aikenhead, G.S., and Elliott, D. 2010. An emerging decolonizing science education in Canada. Canadian Journal of Science, Mathematics and Technology Education 10(4):321-338. https://doi.org/10.1080/14926156.2010.524967

Alexander, S.M., Provencher, J.F., Henri, D.A., Taylor, J.J., Lloren, J.I., Nanayakkara, L., Johnson, J.T., and Cooke, S.J. 2019. Bridging Indigenous and science-based knowledge in coastal and marine research, monitoring, and management in Canada. Environmental Evidence 8: 36.

https://doi.org/10.1186/s13750-019-0181-3 
Barnhardt, R., and Kawagley, A.O. 2005. Indigenous knowledge systems and Alaska Native ways of knowing. Anthropology \& Education Quarterly 36(1):8-23.

https://doi.org/10.1525/aeq.2005.36.1.008

Burke, D.C. 2019. Canadian High Arctic Research Station and Cambridge Bay: An interview with Marla Limousin. Arctic 72(3):329-334.

https://doi.org/10.14430/arctic69026

Christopher, N., Flaherty, L., and McDougall, L. 2009. Stories of the Amautalik: Fantastic beings from Inuit myths and legends. Iqaluit, Nunavut: Inhabit Media.

Costanza, R., Daly, L., Fioramonti, L., Giovannini, E., Kubiszewski, I., Mortensen, L.F., Pickett, K.E., Ragnarsdottir, K.V., de Vogli, R., and Wilkinson, R. 2016. Modelling and measuring sustainable wellbeing in connection with the UN sustainable development goals. Ecological Economics 130:350-355.

https://doi.org/10.1016/j.ecolecon.2016.07.009

Fontanella, J.E., Fish, J.E., Rybczynski, N., Nweeia, M.T., and Ketten, D.R. 2011. Three-dimensional geometry of the narwhal (Monodon monoceros) flukes in relation to hydrodynamics. Marine Mammal Science 27(4):889-898.

https://doi.org/10.1111/j.1748-7692.2010.00439.x

Gearheard, S., Matumeak, W., Angutikjuaq, I., Maslanik, J., Huntington, H.P., Leavitt, J., Kagak, D.M., Tigullaraq, G., and Barry, R.G. 2006. "It's not that simple": A collaborative comparison of sea ice environments, their uses, observed changes, and adaptations in Barrow, Alaska, USA, and Clyde River, Nunavut, Canada. Ambio 35(4):203-211.

https://doi.org/10.1579/0044-7447(2006)35[203:INTSAC]2.0. $\mathrm{CO} ; 2$

Green, L.J.F. 2008. 'Indigenous' knowledge and 'science': Reframing the debate on knowledge diversity. Archaeologies 4(1):144-163. https://doi.org/10.1007/s11759-008-9057-9

Halliday, M. 2020. In Canada, Inuit communities are shaping research priorities. Undark, May 27. https://undark.org/2020/05/27/canada-inuit-research/

Huntington, H.P. 2000. Using traditional ecological knowledge in science: Methods and applications. Ecological Applications 10(5): 1274 .

https://doi.org/10.1890/1051-0761(2000)010[1270:utekis]2.0. co;2

-2002. Traditional knowledge of the ecology of belugas, Delphinapterus leucas, in Cook Inlet, Alaska. Marine Fisheries Review, 62(3):134-140. https://aquadocs.org/handle/1834/26390

- 2011. The local perspective. Nature 478:182-183. https://doi.org/10.1038/478182a

Kourantidou, M., Hoover, C., and Bailey, M. 2020. Conceptualizing indicators as boundary objects in integrating Inuit knowledge and Western science for marine resource management. Arctic Science 6:279-306. https://doi.org/10.1139/as-2019-0013
Krupnik, I. 2009. "The way we see it coming”: Building the legacy of Indigenous observations in IPY 2007-2008.” In: Krupnik, I., Lang, M.A., and Miller, S.E., eds. Smithsonian at the poles: Contributions to International Polar Year science. Washington, D.C.: Smithsonian Scholarly Press. 129-142. https://doi.org/10.5479/si.097884601X.11

Krupnik, I., Bravo, M., Csonka, Y., Hovelsrud-Broda, G., MüllerWille, L., Poppel, B., Schweitzer, P., and Sörlin, S. 2005. Social sciences and humanities in the International Polar Year 2007-2008: An integrating mission. Arctic 58(1):91-97. https://doi.org/10.14430/arctic400

Moore, S.E., and Huntington, H.P. 2008. Arctic marine mammals and climate change: Impacts and resilience. Ecological Applications 18(sp2):S157-S165.

https://doi.org/10.1890/06-0571.1

Moore, S., and Galway, G. 2018. Design and pedagogical practices of an Inuit-focused Bachelor of Education program in Labrador. Education in the North 25(1-2):155-174.

https://aura.abdn.ac.uk/bitstream/handle/2164/15824/ Moore_etal_EITN_design_padagogical_practices_VOR. pdf?sequence $=2$

Ng'Asike, J.T. 2011. Turkana children's rights to education and Indigenous knowledge in science teaching in Kenya. New Zealand Journal of Teachers' Work 8(1):55-67.

Nweeia, M.T. 2020. Inuit knowledge and the science of narwhal population dynamics, behaviour, and biology. In: Krupnik, I., ed. Arctic crashes: People and animals in the changing Arctic: North. Washington D.C.: Smithsonian Institution Press. 216-234.

Nweeia, M.T., Nutarak, C., Ootoova, E., Sanguya, P., Orr, J., Meehan, J., and Angnatsiak, D. 2009. Inuit Qaujimajatuqangit of the narwhal: Traditional knowledge integrated with tusk scientific research. In: Collignon, B., and Therrien, M., eds. Orality in the 21st century: Inuit discourse and practices. Proceedings of the 15th Inuit Studies Conference, 26-28 October 2006, Paris, France. 22 p.

http://www.inuitoralityconference.com/art/NweeiaAngnasiak-Sanguya.pdf

Nweeia, M.T., Eichmiller, F.C., Hauschka, P.V., Tyler, E., Mead, J.G., Potter, C.W., Angnatsiak, D.P., Richard, P.R., Orr, J.R., and Black, S.R. 2012. Vestigial tooth anatomy and tusk nomenclature for Monodon monoceros. The Anatomical Record 295(6):1006-1016.

https://doi.org/10.1002/ar.22449

Nweeia, M.T., Eichmiller, F.C., Hauschka, P.V., Donahue, G.A., Orr, J.R., Ferguson, S.H., Watt, C.A., et al. 2014. Sensory ability in the narwhal tooth organ system. The Anatomical Record 297(4):599-617. https://doi.org/10.1002/ar.22886

Nweeia, M.T., Angnatsiak, D., Nielsen, P., Nutarak, C. 2017. Inuit contributions to narwhal knowledge. In: Fitzhugh, W.W., and Nweeia, M.T., eds. Narwhal: Revealing an Arctic legend. Hanover, New Hampshire: IPI Press; Washington, D.C.: Arctic Studies Center, National Museum of Natural History, Smithsonian Institution. 123-131. 
Oosten, J., Laugrand, F.B., and Trudel, F. 2012. Representing Tuurngait: Memory and history in Nunavut. Vol. 1. Iqaluit: Nunavut Arctic College.

Peeters, P. 2013. Eco hero: De weg naar gezond eten en duurzaam leven [Eco hero: The road to healthy eating and sustainable living]. Ghent, Belgium: Borgerhoff \& Lamberigts. 256 p.

Peeters, P. 2017. Rethinking human development. In: Fitzhugh, W.W., and Nweeia, M.T., eds. Narwhal: Revealing an Arctic legend. Hanover, New Hampshire: IPI Press; Washington, D.C.: Arctic Studies Center, National Museum of Natural History, Smithsonian Institution. 173.

Rapinski, M., Payette, F., Sonnentag, O., Herrmann, T.M., Royer, M.-J.S., Cuerrier, A., Collier, L.S., et al. 2018. Listening to Inuit and Naskapi peoples in the eastern Canadian Subarctic: A quantitative comparison of local observations with gridded climate data. Regional Environmental Change 18:189-203. https://doi.org/10.1007/s10113-017-1188-3

Richard, W. 2019. Between sea and glacier: Greenland in a changing world. Hanover, New Hampshire: IPI Press. 256 p.

Riggs, E.M. 2005. Field-based education and Indigenous knowledge: Essential components of geoscience education for Native American communities. Science Education 89(2):296-313.

https://doi.org/10.1002/sce.20032
Shizha, E. 2007. Critical analysis of problems encountered in incorporating Indigenous knowledge in science teaching by primary school teachers in Zimbabwe. Alberta Journal of Educational Research 53(3):302-319.

Snively, G., and Corsiglia, J. 2001. Discovering Indigenous science: Implications for science education. Science Education 85(1):6-34. https://doi.org/10.1002/1098-237x(200101)85:1\%3C6::aidsce3\%3E3.0.co;2-r

Swift, D. 1992. Indigenous knowledge in the service of science and technology in developing countries. Studies in Science Education 20(1):1-28. https://doi.org/10.1080/03057269208560002

United Nations. 2015. The 17 goals. New York: Division for Sustainable Development Goals, Department of Economic and Social Affairs.

https://sdgs.un.org/goals

Weatherhead, E., Gearheard, S., and Barry, R.G. 2010. Changes in weather persistence: Insight from Inuit knowledge. Global Environmental Change 20(3):523-528. https://doi.org/10.1016/j.gloenvcha.2010.02.002

Wenzel, G. 1991. Animal rights, human rights: Ecology, economy and ideology in the Canadian Arctic. Toronto, Ontario: University of Toronto Press. 